\title{
Psychic burden development related to nursing work in Psychosocial Care Centers
}

\author{
Desenvolvimento de cargas psíquicas relacionadas ao trabalho da enfermagem em Centros de Atenção Psicossocial
}

Desarrollo de cargas psíquicas relacionadas con el trabajo de enfermería en los Centros de Atención Psicosocial

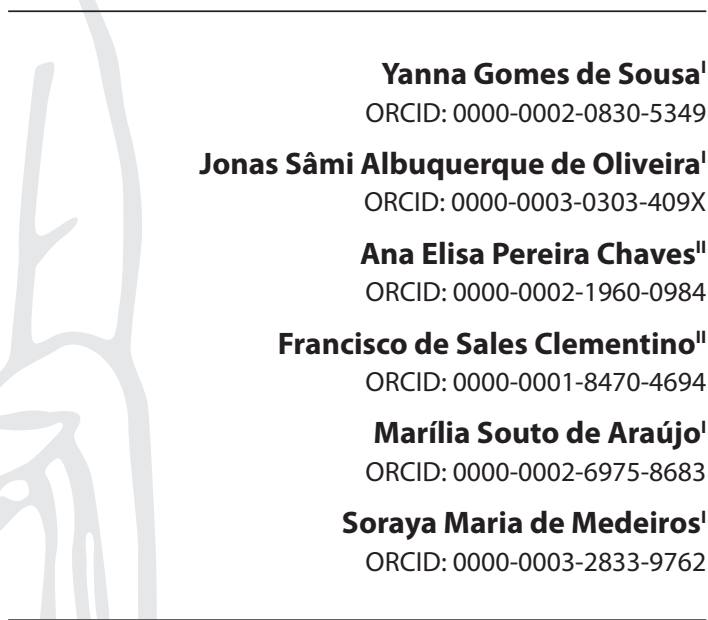

-Universidade Federal do Rio Grande do Norte. Natal, Rio Grande do Norte, Brazil. "-Universidade Federal de Campina Grande. Campina Grande, Paraíba, Brazil.

How to cite this article: Sousa YG, Oliveira JSA, Chaves AEP, Araújo MS Clementino FS, Medeiros SM. Psychic burden development related to nursing work in Psychosocial Care Centers.

Rev Bras Enferm. 2021;74(Suppl 3): e20200114. doi: http://dx.doi.org/10.1590/0034-7167-2020-0114

\section{Corresponding author:}

Yanna Gomes de Sousa

E-mail:yanna_gomes@yahoo.com.br

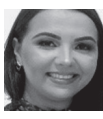

EDITOR IN CHIEF: Antonio José de Almeida Filho ASSOCIATE EDITOR: Priscilla Broca

Submission: $04-17-2020$

Approval: $10-06-2020$

\section{ABSTRACT}

Objective: to investigate the factors that are present in the work environment of the nursing team and that contribute to emergence of psychic burden in Psychosocial Care Centers III. Methods: this is a descriptive and qualitative study carried out in three services located in Paraíba State. Data were obtained from an interview with a semi-structured script, and textual content was treated using the software Interface de R pour Analyzes Multidimensionnelles de Textes et de Questionneires. Results: the factors that trigger psychic burden arise primarily from pace of work, precarious physical structure, work with users in mental distress, lack of management support, insufficient multidisciplinary team and lack of clinical supervision. Conclusion: the difficulties faced by nursing professionals in the work environment cause suffering at work and hinder the effectiveness and, consequently, the quality of nursing care. Descriptors: Nursing; Work; Mental Health Services; Occupational Health; Workload.

\section{RESUMO}

Objetivo: investigar os fatores que estão presentes no ambiente de trabalho da equipe de enfermagem e que contribuem para o surgimento das cargas psíquicas de trabalho em Centros de Atenção Psicossocial III. Métodos: estudo descritivo, de abordagem qualitativa, realizado em três serviços localizados no estado da Paraíba. Os dados foram obtidos a partir de entrevista com roteiro semiestruturado, e o conteúdo textual foi tratado por meio do software Interface de R pour Analyses Multidimensionnelles de Textes et de Questionneires. Resultados: os fatores desencadeantes das cargas psíquicas surgem prioritariamente a partir do ritmo de trabalho, da estrutura física precária, do trabalho com usuário em sofrimento mental, da falta de apoio da gestão, da equipe multidisciplinar insuficiente e da falta de supervisão clínica. Conclusão: as dificuldades enfrentadas pelos profissionais de enfermagem no ambiente laboral ocasionam sofrimento no trabalho, prejudicando a efetividade do atendimento e, consequentemente, a qualidade da assistência de enfermagem.

Descritores: Enfermagem; Trabalho; Serviços de Saúde Mental; Saúde do Trabalhador; Carga de Trabalho.

\section{RESUMEN}

Objetivo: investigar los factores que se encuentran presentes en el ambiente laboral del equipo de enfermería y que contribuyen al surgimiento de cargas de trabajo psíquicas en los Centros de Atención Psicosocial III. Métodos: estudio descriptivo con abordaje cualitativo, realizado en tres servicios ubicados en el estado de Paraíba. Los datos se obtuvieron de una entrevista con un guión semiestructurado, y el contenido textual se trató con el software Interface de R pour Analyzes Multidimensionnelles de Textes et de Questionneires. Resultados: los factores desencadenantes de cargas psíquicas surgen principalmente del ritmo de trabajo, la precaria estructura física, el trabajo con usuarios en distrés mental, la falta de apoyo gerencial, el insuficiente equipo multidisciplinario y la falta de supervisión clínica. Conclusión: las dificultades que enfrentan los profesionales de enfermería en el ámbito laboral provocan sufrimiento en el trabajo, afectando la efectividad del cuidado y la calidad del cuidado de enfermería.

Descriptores: Enfermería;Trabajo; Servicios de Salud Mental; Salud Laboral; Carga de Trabajo. 


\section{INTRODUCTION}

The transformations that have occurred in the last decades in the world of work have had an impact on individuals' and workers' health. In the work environment, the man interprets the reality of work, and, not being indifferent to it, they react in a physical, mental and affective way, producing changes in their psychic reality. Thus, the relational dimension resulting from confrontation between subject and work affects workers' mental health. The daily experience at work, its organization, planning and execution, associated with the relationships established with the various actors, can define the quality of workers' psychological well-being ${ }^{(1-2)}$.

Nursing, with a work proposal based on the consolidation of comprehensive practice and away from fragmented assistance that disregards subjectivity, social, ethical and humanistic commitment, from the emergence of the Brazilian Psychiatric Reform (PR) movement, begins to (re) build its knowledge, care, and, consequently, its technological advancement in institutions that substitute psychiatric hospitals ${ }^{(2)}$, aiming to guarantee universal access and comprehensive quality care for people in psychological distress ${ }^{(3)}$.

However, this model has been permeated by contradictions and a wide intrinsic problem in the process of implementation of this equipment. It is noteworthy that the daily work of Psychosocial Care Centers (CAPS - Centros de Atenção Psicossocial) involves arduous moments for teams due to numerous and complex challenges to be faced such as: inadequate infrastructure; lack of logistical support (cleaning materials, office supplies, medicines, transport); lack of professionals, among others. Countless conditions related to the management of the Unified Health System (SUS - Sistema Único de Saúde) cut across the teams' work, greatly restricting the possibilities of intervention ${ }^{(2,4-5)}$.

In the nursing work context at CAPS, precarious working conditions offered to workers and the specificity of the work reality, which is the direct contact with service users' mental distress, interfere with professionals' mental health and this can trigger feelings of anguish, distress, and frustration ${ }^{(6-7)}$. In this regard, the nursing work developed at CAPS has very specific aspects, which sometimes reverberate negatively, with the development of an excessive workload in this professional category.

Nursing workload is influenced by factors specific to the profession, with high emotional implications, and by factors related to the forms of work organization. In this regard, nursing professionals' work is endowed with social stressors (taking care of the other), labor (excessive workloads) and professional (permanent confrontation with the suffering of the other) stressors that translate into workloads in this process ${ }^{(2,8)}$. Psychic burden development is influenced by the form of organization and working conditions and results from the confrontation of workers' desires with the employers' injunction, who have a personal history, motivations and psychological needs that give them unique characteristics. Psychic burden is represented as a result of confrontation between the wishes of workers and the institution. If the relationship established between workers and the institution is unbalanced and if no changes happen, the domain of suffering opens up, which can trigger illness ${ }^{(9)}$.

In Brazil, there is little research that investigated the development of nursing workers' workloads at CAPS III; however, those that analyzed are concentrated in the psychiatric hospital setting ${ }^{(10-11)}$.
Given the above the following guiding question of the research was delimited: what factors contribute to the emergence of psychic burden by nursing professionals?

\section{OBJECTIVE}

To investigate the factors that are present in the work environment of the nursing team and that contribute to emergence of psychic burden at Psychosocial Care Centers III.

\section{METHOD}

\section{Ethical aspects}

This research was approved by the Research Ethics Committee of Universidade Federal do Rio Grande do Norte (UFRN). All participants were informed about the objectives of the study and, upon agreeing to participate, signed the Informed Consent Form (ICF).

\section{Type of study}

This is an exploratory-descriptive and qualitative study, whose reference scope was the development of Christophe Dejours'Psychic Suffering. The software Interface de R pour Analyses Multidimensionnelles de Textes et de Questionneires (IRAMUTEQ) was used ${ }^{(12)}$.

\section{Methodological procedures}

Initially, there was a survey of CAPS III services enabled in Paraíba State. After this stage, contact was made with the Municipal Health Departments with those responsible for services, in order to explain the purpose of the research and request an appointment with the respective coordinators to present the research project to nursing professionals and carry out planning to start the interviews.

To achieve the objectives proposed by the study, there was a delimitation of the enrolled subjects. Professionals belonging to the CAPS III nursing team for over a year and in activity were included. Workers on sick leave, leave and vacation during the data collection period were excluded ${ }^{(2)}$.

\section{Data source}

The study population consisted of 50 nursing workers (nursing technicians and nurses) who were invited to participate in the study. However, four nursing technicians were excluded; of these, two did not accept to participate in the study, one was assigned to the therapeutic residency and one met the exclusion criteria of the study.

The study included 27 nursing technicians and 19 nurses, totaling 46 participants. To preserve their identity, their statements were identified by letter $\mathrm{E}$ of interviewee, followed by a number in sequential order (11, 12, 13, 14, successively, up to 146).

\section{Data collection and organization}

Data collection took place from August to September 2016, from the application of an interview with a semi-structured script, and from a literature review, with aspects related to the psychic burden of nursing professionals. All interviews were conducted using an MP4 recorder by the researcher herself in the morning, afternoon, and evening, upon scheduling. The interviews lasted between 30-40 
minutes. After they ended, a participant was asked if he or she would like to hear the recording. All interviews were transcribed according to the criterion of fidelity for each speech collected ${ }^{(2)}$.

\section{Data analysis}

After conducting the interviews, the process of analyzing the textual data obtained began, thus, after transcription, the textual corpus was configured so that it could be inserted in IRAMUTEQ ${ }^{(12)}$. The configuration followed the following procedures: all content (interviews) was placed in a single text file in Open Office 4.1, since Microsoft applications (Word, Excel, WordPad or Notepad) cannot be used in the analysis via IRAMUTEQ ${ }^{(12)}$, as they produce bugs with Unicode (UTF-8).

Then, the texts were separated from command lines (with asterisks) so that each interview was recognized by the software as a text. The entire file was revised and corrected according to the specific IRAMUTEQ standard ${ }^{(12)}$ regarding typos, punctuation, use of acronyms, use of hyphenated compound words and use of verbs in their pronominal form. After preparing the file with the corpus at OpenOffice.org, a folder was created on the desktop only for data analysis through IRAMUTEQ ${ }^{(12)}$.

Data were imported into the program to work on its interface. IRAMUTEQ segments the text, establishing similarities between the segments and hierarchies of word classes. This occurs with the following steps: identification of words and their reduced forms (roots); segmentation of discursive material into Elementary Context Units (ECUs); delimitation of semantic classes, followed by their description through the quantification of the reduced forms and function of ECUs, as well as the connections established between them; analysis of the association and correlation of the variables reported to the classes obtained; analysis of the connections established between the typical words in function of classes (dendogram).

\section{RESULTS}

Semi-structured interview script had the collaboration of 46 nursing workers from CAPS III, being $58.7 \%$ nursing technicians and $41.3 \%$ nurses. Of these, females (80.40\%), aged between $25-35$ years (39.13\%) and married (41.30\%) figured prominently, with the following functional profile:

Table 1 - Functional profile of nursing workers enrolled in Psychosocial Care Center III (N=46), Campina Grande and João Pessoa, Paraíba, Brazil, 2016 (2)

\begin{tabular}{llc}
\hline Employee profile & & $\mathbf{n}(\%)$ \\
\hline Time working in mental & Up to 5 years & $31(67.39)$ \\
health & - 10 years & $9(19.57)$ \\
& Over 10 years & $6(13.04)$ \\
Time spent with & $21-30$ hours/week & $25(54.35)$ \\
mentally ill people & $31-40$ hours/week & $20(43.48)$ \\
& Above 40 hours/week & $1(2.17)$ \\
Main activity performed & Physical health care & $44(95.65)$ \\
(Multiple response) & General care & $43(93.48)$ \\
& Pharmacological therapy & $31(67.39)$ \\
& Counseling & $14(30.43)$ \\
& Therapeutic workshops & $8(17.39)$ \\
Total & Rehabilitation activity & $2(4.35)$ \\
& & $46(100)$ \\
\hline
\end{tabular}

Using lexical analysis, after reducing the words to their roots, a total of 2,956 different words were obtained, with 445 different forms. There was a number of texts equal to 46 (UCls) divided into 73 Text Segment Units (ECUs) ${ }^{(2)}$. With regard to the emergence of psychic burdens in nursing teams at CAPS III, there is greater significance as shown in Figure 1, generated from the data emitted by IRAMUTEQ, presented below.

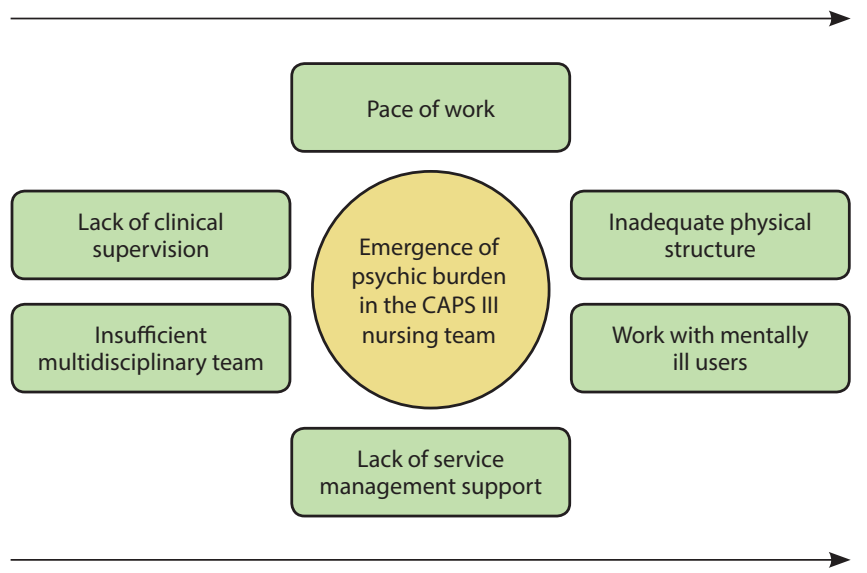

Figure 1 - Elements responsible for triggering psychic burden in the Psychosocial Care Center III nursing team. Campina Grande, João Pessoa, Paraíba, Brazil, 2016

From the results obtained, it was found that during the daily work the nursing team was exposed to numerous factors that contributed to generating psychic burden, some of which are inherent in the nursing work itself, others with a clear relationship with working conditions, work organization, and service management. In all CAPS III surveyed, the main elements that contributed to the emergence of psychic burden were related to: pace of work; physical structure; work with users; lack of management support; insufficient multidisciplinary team and lack of clinical supervision.

The CAPS nursing team realized that the daily pace of work in service was permeated with elements that contributed to developing tiredness, fatigue, and insomnia. Thus, when labor demands are perceived by workers as exceeding their mental structure, professionals' physical and mental exhaustion emerge. As revealed in the following statements:

We feel the weight of physical and mental wear and tear over theyears. Ifeel my mood changes, I always get upset and sometimes sad. (I04)

I found that I became intolerant of loud sound, noise and loud parties. I feel mentally tired and stressed. There are many years of work here in this CAPS without vacation, thirteenth salary, living wage, working conditions. I stay here for the patients. $(105)^{(2)}$

Ifeel anxiety, headache, fatigue, body fatigue, insomnia, restlessness and all this leads to physical and mental tiredness. We are forgotten and so we get sick inside ${ }^{(2)}$. Where is the look of mental health management for the professionals who are here? Late wages. (108)

My pace of work causes me headache, fatigue, body fatigue, insomnia, restlessness and all of this leads to physical and mental tiredness. We are forgotten and, therefore, we get sick here [...] it 
would be important that a team of professionals from outside CAPS could come to support us to promote mental health within our work environment, such as the offer of psychotherapy individual to help us deal with problems. (I32) (2)

The services' physical structure is also responsible for causing dissatisfaction and demotivation, and this has a negative impact on the development of professionals' daily practices in the context of mental health.

We have been here for 10 years in this building without renovation and it is small for the number of patients. We have problems with bathrooms, water, energy, chairs for employees and patients ... it is hard to work like this. (I09)

CAPS' physical structure is precarious, mainly because we have small rooms with plaster walls, with little space, lack of room for individual assistance. Another problem I see is a very high staircase that leads to the $1^{\text {st }}$ floor. During a psychiatric crisis, patients can push us as well as fall. Another problem I see is the balcony on the $1^{\text {st }}$ floor of CAPS, which, despite having a screen, several patients have tried to jump, in addition to the exhaustion of their own work, they are still concerned with the physical safety of users. (I11) ${ }^{(2)}$

I get stressed about having to improvise here all the time, the service doesn't have adequate physical space. I am discouraged by the working conditions offered here at CAPS III. I wear myself out a lot for that ${ }^{(2)}$. Sometimes I come home mentally worn out, with no mood to deal with my family. Sometimes I wonder if I can handle what I'm doing here at CAPS III and I suffer for it. How is psychosocial rehabilitation promoted without working conditions? Are the managers unaware of this? (I17)

The physical structure of this CAPS is terrible. Much is missing here. They need to improve the bathrooms, the service rooms, broken faucet, broken sink, bathroom plumbing are terrible. (125) ${ }^{(2)}$

The nursing team was also faced with damage in personal and family relationships due to the general fatigue resulting from work in these centers. There was a lack of cohesion between personal life and the work environment.

Sometimes I feel upset, stressed and nervous with so much physical and mental stress that I face here at work and I think I absorb it in a negative way. I get home without patience, I don't want to hear anyone talking near me, much less the noise of my children. I only think about sleeping. $(101)^{(2)}$

Sometimes I come home mentally worn out and in no mood to deal with my husband and children. I feel very tired physically at the end of the shift, when I get home, my house is a mess and I am not even able to fix it, I am so tired that I arrive. I am aware that it is the problems here at work that affect me. (115) (2)

Another aspect evidenced, in most statements, was the exhaustion arising from the specificity of the public's needs met, i.e., the other's mental suffering.

Of the activities that I perform here, the one that brings me the most physical and mental wear is the issue of the service itself to users in mental distress. This leads me to feel physical tiredness, back pain, anxiety, overload, stress, mood swings and fatigue ${ }^{(2) !}$ Now you're seeing a schizophrenic, then a bipolar, one who tried suicide, depression. And having patience for all this? Being resolutive in nursing care? Just know who's here. (120)

I feel a lot of physical and mental stress when I am providing assistance to users in crisis, as they, when agitated, stress me out here. My work brings me problems with sleep, anxiety, intolerance, mood swings, exhaustion, fatigue and overload. And it happens very often in my life. I have gastritis problems due to my anxiety. Especially in the week that I pick up shifts with users in psychotic outbreak. (121) (2)

Dealing with disorders makes us add up a lot and this ends up affecting our health a little. Working with the other's mind and developing ours is very complicated. (I35)

Dissatisfaction with the treatment given by CAPS III management was reported by all participants and this had a negative impact on the daily work of the nursing team. The low support received increases feelings of demotivation, mood swings, anguish and sadness in the workplace.

We don't have a look at management for professionals working in mental health. Working conditions are lacking, because the service's physical structure is precarious, medicines are lacking and the user is in crisis all the time, because he or she cannot afford to buy the medicines, there is no material for therapeutic workshops. Lack of management support. Nobody asks us how we are doing, what needs to improve, nothing. This causes anguish among professionals, we are unmotivated here. $(112)^{(2)}$

Management support would be important, with a different look at mental health to organize working conditions. Support from the health network, greater appreciation for mental health of the entire management of the Health Department, the family health team, SAMU and all professionals. We need psychological support as well and that is in a planned and routine way, because we have nothing specific for our mental health. We are sad and unmotivated. Nobody cares about our anguish. (144) (2)

Another problem encountered by the interviewees was the insufficient multidisciplinary team at CAPS III. This aspect contributes to developing tiredness, irritability, and stress.

I have a lot of work overload since the multidisciplinary team of professionals was reduced, I am getting very tired, because the tasks that were performed by professionals in other categories are now with me. I've been overworked for six months, because I've taken functions from others who have been turned off. (I10)

The worst thing here is the insufficient number of nursing professionals, the number is insufficient for the demand of CAPS III. And it overloads those on duty. Working with a reduced team is very difficult, I get angry and stressed. We have over 800 active users here at this CAPS III. (140) $)^{(2)}$

Some reports also pointed to the fragility of the quality of nursing care provided due to lack of institutional clinical supervision.

Lack of clinical supervision in monitoring case studies generates anguish and anxiety in nursing professionals who work here 
at CAPS III. Without supervision, I think the team is left with no direction to outline some strategies. (I07)

Imiss having clinical supervision in the dailymonitoring, in case studies, and this ends up generating anxiety in the professionals who work here at CAPS. This is our request! But management says it doesn't have the money for it. That the Ministry of Health no longer orders. I know that, if the Health Officer wanted, he could invest the money from the CAPS resource for supervision, and why not? I already consulted the technical mental health management of the Ministry of Health about the payment of supervision and it can be done by the municipality! This is frustrating! Lack of commitment to mental health. (I25)

The lack of clinical supervision at CAPS III generates a burnout in the professional because there are times that I think our work does not flow, you know. This creates stress. (129)

\section{DISCUSSION}

Despite analyzing a specific reality and facing a logic that signals ruptures and overcoming the asylum model, since PR in Brazil has made significant progress in investing in deinstitutionalization, with the implementation of extra-hospital and community actions, it is emphasized that in Brazil, especially in recent years, a current scenario is pointed out with numerous challenges in the struggle for PR and SUS, which suffer from structural problems of financing and low capacity to absorb new challenges ${ }^{(13)}$.

Furthermore, the problem with the working conditions of nursing teams emerges as a serious problem in the health field in Brazil. This includes deficits in the workforce's quantity and quality, which negatively impacts nursing professionals' health and affects the way service users are welcomed and cared for, and the effectiveness and quality of the care provided ${ }^{(14)}$.

In this study, the results pointed to the dominance of situations that generate psychological workloads for nursing professionals. Among the elements that contributed to the development of these loads, there are several elements related to work management failures and the current working conditions of CAPS III. For this reason, it is necessary, from the context analyzed here, to reflect on what is announced as reform and what is effective as nursing work. The teams at these centers have listed barriers that compromise PR solidification. These problems faced may be the effects of a reformist process with insufficient managerial and political support to effect, within the scope of services, the construction of a RAPS committed to the effectiveness of its guidelines.

It is understood, in relation to pace of work, that situations of wear and tear in the work environment cause the emergence of stress for workers. Moreover, professionals worn out in the work environment are more likely to commit negligence in relation to certain behaviors, thus compromising the quality of care provided and causing harm to the person being assisted ${ }^{(2,15)}$. The challenge is political and requires ongoing commitment to building new ways of dealing with psychological suffering. Thus, the need for intersectoral dialogue between the services that make up RAPS in Brazilian municipalities, such as CAPS, outpatient clinics, therapeutic residences and the psychiatric hospital itself, is reinforced, due to the few advances achieved in recent years ${ }^{(16)}$.

In this study, it was found that precarious physical structure is responsible for physical and mental stress in nursing workers.
This directly influences the conditions of engagement of workers, since it generates conflict between workers' subjectivity and their work reality, contributing to psychic energy accumulation ${ }^{(9)}$. The suffering generated by the work environment, especially due to working conditions, can become intense, permeated by anguish, particularly when workers are exposed for a long period of time ${ }^{(15)}$. It is important to highlight that, at the present time of CAPS services, the nursing teams of these centers have faced working conditions that demand a certain expenditure of energy and adaptation, with emphasis on the psychic meanings, with a greater probability of the occurrence of unpleasant feelings and emotions. This has consequences for the organism, such as fatigue, irritability, instability of character, depression and somatization, which can manifest in illness and, consequently, contribute to workers' physiological degradation ${ }^{(13)}$.

Considering the issues listed in relation to CAPS' physical structure of and workers' exhaustion, the existence of dissonances between the guidelines of the Brazilian National Mental Health Policy (Política Nacional de Saúde Mental) and the working environment of these workers is considered. This may be the result of a reformist process with insufficient managerial and political support to effect, in the scope of services, the construction of a place with adequate working conditions for workers, making the quality of care provided to users in mental suffering to be compromised. It should be noted that, with regard to valorization of workers' mental health, the III Brazilian National Conference on Mental Health discussed the instruments for building and consolidating an adequate human resources policy, consistent with the PR principles ${ }^{(17)}$.

It is believed that the improvement in CAPS III's physical structure may raise the feelings of support and security for professionals, contributing to more qualified and competent user care. Thus, the need to adopt measures by the public administration is emphasized, in order to make possible a work management policy to overcome precarious work relationships. There were similar findings in a study ${ }^{(18)}$ carried out in mental health services, which corroborates these results and points out that the main causes of exhaustion on workers are aspects inherent to the physical structure, such as place inadequacy and environment precariousness.

It was evidenced in this study that the work with the other's mental suffering was considered demanding and exhausting, permeated by situations of suffering, illness and emotional exhaustion. It is understood that the encounter between nursing workers and mentally ill users in daily care is challenging and may be responsible for causing great vulnerability of workers to burnout. They are exposed to the dichotomous experience of feelings experienced at work, in addition to the frequent feeling of impotence in the face of various pain conditions, which, taken as a whole, favor human exhaustion intensely ${ }^{(19-20)}$.

It is still worth mentioning that there is an ideological advance in the psychosocial way in caring for users in mental suffering; however, from workers' point of view, there is a need to modify, transform and minimize the perception of reality that makes them suffer. Thus, managers need to direct efforts towards the work process organization, with a view to the work object itself and its consequences on workers' health and quality of life. Furthermore, they should use the 
Integrative and Complementary Practices Policy as a SUS policy, in favor of professional care, as an agenda in the service itself.

Concerning the work management of the CAPS III surveyed, it was noticed that there are many obstacles faced by nursing workers in the daily life of CAPS. It is noteworthy that, when workers are reduced to an object that obeys "who understands the subject", in general managers who plan the dynamics of assistance away from the space where the work is performed ${ }^{(19)}$, there is the emergence and development work overload and emotional exhaustion of workers ${ }^{(21-22)}$. However, there is evidence that, when professionals manage the unit in a shared way with the health team, through technical team meetings, empowering all actors in the service, there is greater individual satisfaction of nursing professionals with work and less perception of physical and psychic burden in daily work ${ }^{(23-24)}$.

In the CAPS III surveyed, it was unanimous among interviewees that there is a need in daily work practice to reduce the inequities present in the relationship between worker and institution. The nursing team aims for a work environment in which it is possible to expand the possibilities of democratization and improvements in CAPS' working conditions and, therefore, obtain an improvement in the quality of nursing care provided.

Considering the insufficient multidisciplinary team of the CAPS surveyed, it was possible to observe the nursing team's work fragmentation and, consequently, losses to a more plural and comprehensive performance by the service professionals. These factors signal not only precarious work in the CAPS III studied, but also the fragility of the care offered in Paraíba's Psychosocial Care Network (RAPS - Rede de Atenção Psicossocial).

Lack of clinical supervision creates anguish for nursing workers. These professionals seek to find support in supervision both for care and in interpersonal relationships, ensuring continuity of work and overcoming difficulties encountered. Clinical supervision is a core practice in the area of mental health, with the effect of structural inclusion in public policy itself. Through clinical supervision, it is possible to problematize the daily situations of CAPS teams through dialogue between participants and different conceptions and fields of work, opening space for new reflections and new agreements. Supervision is a comprehensive feature of the Brazilian National Mental Health Policy, not as something peripheral, contingent or casual, but affirmed as essential for the national mental health network construction; therefore, it is necessary for care management of users in mental suffering.

Another aspect that should be considered by the management of these centers, aiming at improving the quality of the care provided, is the Permanent Health Education Policy implementation as an important instrument for assessing and monitoring the teams' work process in mental health care. This instrument is established as a possible strategy in restructuring services, based on analysis of social and economic determinants, and, above all, of values and concepts presented by health professionals. It is a policy that considers management, worker, user and training center, with the production of meetings that provide autonomy for users and for the health team's work, in the sense of expanding its network of existential connections ${ }^{(25)}$.
It is noteworthy that the problems faced by the nursing professionals in this study contribute to the intensification of psychological workloads. Therefore, there is a need for investments to integrate the team of professionals and develop interdisciplinary dialogue. It is important to emphasize that the improvement of working conditions can reduce the exposure to psychic burden and wear and tear at work. Thus, workers are more satisfied and, consequently, there is an improvement in the quality of care provided. The sensitivity of service management in increasing the number of workers in CAPS III and organizing its workforce according to services' real needs is also important ${ }^{(2)}$.

\section{Study limitations}

The limitations of this study are associated with the fact that the data reflect a specific reality. Its results cannot be generalized to other services in the intersectoral care network. However, it is believed that it has potential, by providing the acknowledgment that there is suffering in nursing work and that it is necessary to implement protection strategies aimed at situations of suffering at work, as well as reducing the factors that cause the emergence of psychic burden.

\section{Contributions to nursing and mental health}

The study's contribution is to rethink the organizational structure of mental health services, with a view to integrating workers who are effectively confronted daily with psychological workloads. It is essential to promote new ways/means of reframing the work environment considering nursing workers' physical and mental health, because these workers who care for also need to be taken care of.

\section{CONCLUSION}

From the development of this study, it was possible to verify the level of wear and suffering of CAPS III nursing professionals, based on the work reality of the services surveyed and the subjectivity of these professionals, which allowed the identification of the psychological loads present in the work environment. Thus, the need to outline spaces for discussion, analysis and reflection of practices in the daily work of CAPS teams is pointed out, based on the Permanent Health Education Policy, as an essential meeting to change this reality.

It is noticed that strengthening the mental health care network requires political commitment, from the governmental level, to guarantee resources to operationalize actions in substitute mental health services. Moreover, the need for intersectoral responses that favor the interrelationship between people with psychological distress, family members and health professionals is reinforced. Furthermore, it is clear that this topic contributes to nursing to develop as a health profession and discipline of scientific knowledge by providing knowledge about the work of these professionals within the scope of a more significant public mental health policy, currently in force in Brazil, in order to correspond to the World Health Organization's priority strategy. 


\section{REFERENCES}

1. Kolhs M, Olschowsky A, Ferraz L. Suffering and defense in work in a mental health care service. Rev Bras Enferm. 2019;72(4):903-9. doi: 10.1590/0034-7167-2018-0140

2. Sousa, YG. Cargas psíquicas de trabalho em profissionais de enfermagem inseridos nos Centros de Atenção Psicossocial III[Dissertação]. Universidade Federal do Rio Grande do Norte; 2016.

3. Zeferino MT, Cartana MHF, Fialho MB, Huber MZ, Bertoncello KCG. Health workers' perception on crisis care in the Psychosocial Care Network. Esc Anna Nery. 2016;20(3):e20160059. doi: 10.5935/1414-8145.20160059

4. Conselho Federal de Psicologia (CFP). Referências Técnicas para Atuação de Psicólogas(os) no CAPS - Centro de Atenção Psicossocial. Brasília: CFP; 2013.

5. Fernandes MA, Silva DRA, Ibiapina ARS, Silva JS. Mental illness and its relationship with work: a study of workers with mental disorders. Rev Bras Med Trab. 2018;16(3):277-86. doi: 10.5327/Z1679443520180110

6. Carreiro GSP, Ferreira Filha MO, Lazarte R, Silva AO, Dias MD. The process of becoming mentally ill among Family Health Strategy workers. Rev Eletr Enferm. 2013;15(1):146-55. doi: 10.5216/ree.v15i1.14084

7. Paiano M, Maftum MA, Haddad MCL, Marcon SS. Mental health ambulatory: weaknesses pointed out by professional. Texto Contexto Enferm. 2016;25(3):e0040014. doi:10.1590/0104-07072016000040014

8. Pires DEP, Bertoncini JH, Trindade LL, Matos E, Azambuja E, Borges AMF. Inovação tecnológica e cargas de trabalho dos profissionais de saúde: uma relação ambígua. Rev Gaúcha Enferm. 2012;33(1):157-68. doi: 10.1590/S1983-14472012000100021

9. Sousa YG, Medeiros SM, Fernandes SMBA, Oliveira JSA, Martino MMF. Workloads of nursing professionals in hospital services for mental health. Int Arch Med. 2016;9(240):1-9. doi:10.3823/2111

10. Augusto MM, Freitas LG de, Mendes AM. Vivências de prazer e sofrimento no trabalho de profissionais de uma fundação pública de pesquisa. Psicol Rev. 2014;20(1):34-55. doi: 10.5752/P.1678-9523.2014v20n1p34

11. Sousa KHJF, Gonçalves TS, Silva MB, Soares ECF, Nogueira MLF, Zeitoune RCG. Risks of illness in the work of the nursing team in a psychiatric hospital. Rev Latino-Am Enfermagem. 2018;26:e3032. doi: 10.1590/1518-8345.2458.3032

12. Vieira GLC. Satisfação e sobrecarga de trabalho entre técnicos de enfermagem de hospitais psiquiátricos. Rev Port Enferm Saúde Mental. 2017;(17):43-49. doi: 10.19131/rpesm.0182

13. Camargo BV, Justo AM. IRAMUTEQ: um software gratuito para análise de dados textuais. Temas Psicol. 2013;21(2):513-8.

14. Dias GC, Furegato ARF.Satisfaction in and impact of work on, the multidisciplinary team in a psychiatric hospital. Rev Enferm UERJ. 2016;24(1):e8164. doi: 10.12957/reuerj.2016.8164

15. Pires DEP, Machado RR, Soratto J, Scherer MA, Gonçalves ASR, Trindade LL. Nurses' workload: lights and shadows in the Family Health Strategy. Rev Latino-Am Enfermagem. 2016;24:e2677. doi: 10.1590/1518-8345.0992.2682

16. Oliveira RJ, Cunha T. Estresse do profissional de saúde no ambiente de trabalho: causas e consequências. Cad Saúde Desenvolv [Internet]. 2014 [cited 2018 Sep 15];3(2):79-93. Available from: https://www.uninter.com/revistasaude/index.php/cadernosaudedesenvolvimento/ article/download/302/238+\&cd=1\&hl=pt-BR\&ct=clnk\&gl=br

17. Pessoa Jr JM, Santos RCA, Clementino FS, Oliveira KKD, Miranda FAN. Mental health policy in the context of psychiatric hospitals: challenges and perspectives. Esc Anna Nery. 2016;20(1):83-9. doi: 10.5935/1414-8145.20160012

18. Silva EA, Costa II. Saúde mental dos trabalhadores em saúde mental: estudo exploratório com os profissionais dos Centros de Atenção Psicossocial de Goiânia/Go. Psicol Rev [Internet]. 2008 [cited 2018 Sep 15];14(1):83-106. Available from: http://pepsic.bvsalud.org/pdf/per/v14n1/v14n1a06.pdf

19. Clementino FS, Miranda FAN, Martiniano CS, Marcolino EC, Pessoa Junior JM, Dias JA. Assessment of organizational structure of centers for psychosocial care in the city of Campina Grande, Paraíba State. Rev Bras Ciên Saúde [Internet]. 2016[cited 2018 Sep 15];20(4):261-8. Available from: periodicos.ufpb.br/index.php/rbcs/article/view/25340.

20. Clementino FS, Miranda FAN, Martiniano CS. Satisfaction and work overload evaluation of employees of Psychosocial Care Centers. Rev Pesqui: Cuid Fundam. 2018;10(1):153-9. doi: 10.9789/2175-5361.2018.v10i1.153-159

21. Nogueira LS, Sousa RMC, Guedes ES, Santos MA, Turrini RNT, Cruz DALM. Burnout and nursing work environment in public health institutions. Rev Bras Enferm. 2018;71(2):336-42. doi: 10.1590/0034-7167-2016-0524

22. Bogaert VP, Clark S, Willems R. Staff engagement as a target for managing work environments in psychiatric hospitals: implications for workforce stability and quality of care. J Clin Nurs. 2013;22(11-12):1717-28. doi: 10.1111/j.1365-2702.2012.04341.x

23. Nascimento DDG, Moraes SHM, Oliveira MAC. Family Health Support Center: suffering from the perspective of psychodynamics of work. Rev Esc Enferm USP. 2019;53:e03423. doi: 10.1590/s1980-220x2018013403423

24. Oliveira JF, Santos AM, Primo LS, Silva MRS, Domingues ES, Moreira FP et al . Job satisfaction and work overload among mental health nurses in the south of Brazil. Ciên Saúde coletiva. 2019;24(7):2593-9. doi: 10.1590/1413-81232018247.20252017

25. Wandekoken KD, Dalbello-Araújo M, Borges LH. Harmful effects of the work process in an Alcohol and Drugs Psychosocial Care Center. Rev Saúde Debate. 2017;41(112):285-97. doi: 10.1590/0103-1104201711223 